\title{
PERLINDUNGAN HUKUM TERHADAP INFORMASI RAHASIA PELAKU USAHA
}

\author{
Muhammad Zen Al-Faqih ${ }^{1}$ \\ Abie Besman
}

Komisi Penyiaran Indonesia Jawa Barat

\begin{abstract}
Legal protection of confidential information businesses have been granted by law in Indonesia. Act No. Act No. 5 of 1999 concerning Prohibition of Monopolistic Practices and Unfair Business Competition ( "UU Anti Monopoli"), Undang-Undang Nomor 30 Tahun 2000 Tentang Rahasia Dagang, and Undang-Undang Nomor 14 Tahun 2008 Tentang Keterbukaan Informasi Publik ("UU KIP”). Verse 17 letter (J) about Freedom of Information Law states that the information should not be disclosed under the verse 3 (1) of the Act states that the UU Rahasia Dagang protection when the information is confidential, has economic value, and is kept confidential through the efforts accordingly. As for the characteristics of trade secret information set out in Chapter 3 verse (2) and (3) are as follows: (i) the information is considered confidential if the information is only known by a particular party or not known by the general public, (ii) the information is considered to have economic value if the confidentiality of the information can be used to carry out activities or commercial business or can increase economic benefits. The provisions of this law has to enclose the Information Commission at the time of settling disputes public information, that businesses that legal status as a public body of his confidential information is protected.
\end{abstract}

Keywords: Legal protection, confidential information, businesses, Information Commission, disputes.

\section{PENDAHULUAN}

Praktik curang dalam persaingan usaha bukan sebuah fenomena baru. Fenomena ini telah terjadi sejak lama, di Belanda pada awal abad 20, tepatnya pada tahun 1919 telah terjadi praktik curang dalam persaingan usaha, yaitu kasus Cohen versus Lindenbaum. Kasus posisinya adalah, Cohen sebagai pesaing usaha Lindenbaum menyuap pegawai Lindenbaum untuk memberikan infomasi rahasia milik Lindenbaum berupa penawaran, langganan, daftar harga, dan lain-lain. Upaya Cohen ini untuk memenangkan persaingan bisnis di bidang percetakan buku di Amsterdam. Berkat upayanya ini, Cohen berhasil memenangkan persaingan dengan Lindenbaum di Amsterdam, Belanda.

Lindenbaum yang mengetahui praktik curang dalam persaingan bisnis ini kemudian mengajukan gugatan terhadap Cohen ke Arrondisement Rechtbank di Amsterdam (pengadilan tingkat pertama). Lindenbaum menyatakan bahwa perbuatan Cohen adalah perbuatan yang melanggar hukum sebagaimana disebut dalam Pasal 1401 BW Belanda (Pasal 1365 BW Indonesia), Lindenbaum menuntut ganti rugi. Di pengadilan tingkat pertama ini Lindenbaum dikalahkan. Lindenbaum kemudian mengajukan banding kepada Gerechtshof (pengadilan 
tingkat banding) di Amsterdam. Majelis hakim juga mengalahkan Lindenbaum dan menyatakan bahwa Cohen tidak melanggar norma-norma hukum di Undang-Undang.

Lindenbaum tidak puas terhadap putusan banding, kemudian mengajukan kasasi kepada Hoge Raad dan putusan Hoge Raad pada tanggal 31 Januari 1919 memenangkan Lindenbaum. Putusan Hoge Raad menyatakan bahwa:

"perbuatan melanggar hukum sesungguhnya tdak hanya perbuatan melanggar Undang-Undang namun juga perbuatan yang melanggar hak orang lain, bertentangan dengan kewajiban hukum si pembuat sendiri atau bertentangan dengan kesusilaan atau dengan kepatutan di dalam masyarakat".

Putusan Hoge Raad ini kemudian memunculkan doktrin baru dalam ilmu hukum, doktrin tentang "perbuatan melawan hukum" (Onrechtmatige daad) yang pemaknaannya lebih luas. Putusan ini telah menjadi standar arrest yang diikuti oleh hakim-hakim pada pengadilan rendahan di negeri Belanda dan juga diikuti oleh hakim-hakim di Indonesia.

Praktik yang terjadi dalam kasus Cohen versus Lindenbaum bukan sesuatu yang tidak mungkin terjadi di Indonesia. Dalam mengantisipasi hal ini Politik hukum (kebijakan di bidang hukum) di Indonesia kemudian melindungi pelaku usaha dari persaingan usaha tidak sehat. Politik hukum ini terlihat dari diberlakukannya Undang-Undang Nomor 5 Tahun 1999 Tentang Larangan Praktik Monopoli Dan Persaingan Usaha Tidak Sehat ("UU Anti Monopoli"), Undang-Undang Nomor 30 Tahun 2000 Tentang Rahasia Dagang ("UU Rahasia Dagang"), dan Undang-Undang Nomor 14 Tahun 2008 Tentang Keterbukaan Informasi Publik ("UU KIP"). Salah satu perlindungan yang diberikan oleh tiga Undang-Undang ini adalah perlindungan informasi usaha yang dapat menimbulkan persaingan usaha tidak sehat.

Pasal 17 huruf b UU KIP menyatakan bahwa untuk memberikan perlindungan usaha yang sehat, berbagai informasi dapat dikecualikan (dirahasiakan). Komisi informasi sebagai lembaga negara yang berwenang untuk menerima, memeriksa, dan memutus sengketa informasi publik melalui lembaga mediasi dan/atau ajudikasi nonlitigasi dari pemohon informasi publik berkewajiban untuk memberikan perlindungan tersebut. Melalui mekanisme penilaian seperti apakah informasi tentang kegiatan usaha yang disengketakan ke Komisi Informasi termasuk ke dalam informasi yang dikecualikan? Hal ini perlu dijawab dengan menggunakan ratio legis berdasarkan UU Anti Monopoli, UU Rahasia Dagang, dan UU KIP.

\section{RUMUSAN DAN IDENTIFIKASI MASALAH}

UU KIP dalam batang tubuhnya tidak terdapat norma-norma yang menjelaskan secara rinci jenis jenis informasi yang dapat dikecualikan dalam rangka memberikan perlindungan usaha yang dapat dijadikan alat uji bagi pelaku usaha yang badan publik dalam menetapkan pengecualian informasi.

Pasal 1 ayat 3 UU KIP menyatakan bahwa Badan Publik adalah lembaga yang pembiayaannya bersumber dari APBN/APBD atau berasal dari sumbangan masyarakat, dan/atau berasal dari bantuan asing. Badan-badan publik terkena kewajiban untuk memberikan informasi publik. Namun tidak semua pelaku usaha dapat disebut sebagai badan publik karena terdapat pelaku usaha yang ternyata membiayai kegiatan usahanya dari dana mandiri ataupun kongsi dengan rekan usahanya. Berdasarkan hal-hal tersebut identifikasi masalahnya adalah sebagai berikut: 
1. Apakah Komisi Informasi sebagai Lembaga Negara memiliki wewenang untuk menafsirkan Pasal 17 huruf b UU KIP?

2. Bagaimana metode menafsirkan Pasal 17 huruf $b$ Undang-Undang KIP agar adanya kepastian hukum bagi pemohon infomasi, pelaku usaha yang juga badan publik, dan Komisi Informasi?

3. Apakah rezim hukum keterbukaan informasi publik juga dapat menjangkau pelaku usaha yang bukan badan publik?

\section{PEMBAHASAN}

\section{Komisi Informasi Berwenang Menafsirkan Pasal 17 Huruf B UU KIP}

Dalam ilmu hukum, penafsiran hukum terhadap norma-norma hukum lazim dilakukan oleh hakim dalam rangka membentuk hukum dan menyelesaikan sengketa di pengadilan. Hakim berfungsi melaksanakan Undang-Undang. Undang-Undang mengatur hal yang bersifat umum (norma-norma umum), hakim yang kemudian menerapkan norma-norma umum tersebut dalam situasi konkrit. Proses menerapkan hukum ini oleh Paul Scholten, ahli hukum Belanda disebut sebagai penemuan hukum (Rechtsvinding). Di dalam hukum terdapat berbagai metode penafsiran dalam menemukan hukum, antara lain: penafsiran sejarah, penafsiran sosiologis, penafsiran otentik, dan penafsiran sistematis.

Selain hakim, pejabat administrasi negara juga lazim melakukan penafsiran hukum. Dalam konteks welfare state, pejabat administrasi bekerja untuk mendorong tercapainya tujuan negara untuk menciptakan keadilan sosial. Dalam melaksanakan tugas dan fungsinya, pejabat administrasi negara diatur oleh norma-norma hukum (asas legalitas). Dalam melaksanakan norma-norma hukum ini, pejabat administrasi menggunakan metode penafsiran untuk menerapkannya dalam situasi konkrit.

Selain dua jenis lembaga tersebut di atas yang menerapkan hukum, terdapat lembaga lain yang berfungsi menerapkan hukum, yaitu lembaga negara bantu, sesuai dengan tugas dan wewenang yang diberikan peraturan perundang-undangan. Pasca reformasi, kemunculan lembaga negara bantu cukup banyak, salah satunya adalah Komisi Informasi. Komisi Informasi dalam sistem ketatanegaraan Indonesia adalah sebagai lembaga negara baru yang disebut sebagai lembaga negara bantu. Komisi Informasi disebut juga sebagai lembaga kuasi negara, kuasi badan peradilan. Komisi Informasi diberi tugas berdasarkan UU KIP adalah menerima, memeriksa, dan memutus perkara sengketa informasi yang disampaikan pemohon informasi. Dalam melaksanakan tugasnya ini maka Komisi Informasi juga menerapkan hukum dan menyesuaikan Undang-Undang dalam situasi konkrit. Komisi Informasi berdasar UU KIP diberi wewenang untuk membuat putusan, yang mana putusannya itu dapat dibanding bahkan dapat dikasasi hingga ke Mahkamah Agung (MA). Berdasarkan tugas yang diberikan oleh UU dapat disimpulkan bahwa Komisi Informasi berwenang untuk menerapkan dan menafsirkan hukum termasuk menafsirkan ketentuan normatif yang terdapat di dalam pasal 17 huruf b UU KIP.

\section{Metode Penafsiran Oleh Komisi Informasi}


Di dalam hukum, terdapat berbagai metode penafsiran hukum. Penafsiran sejarah, penafsiran sosiologis, penafsiran otentik, dan penafsiran sistematis. Dalam konteks penafsiran terhadap Pasal 17 huruf b UU KIP, Komisi Informasi dapat menggunakan metode penafsiran sejarah dengan mempelajari perdebatan pada saat pembahasan ketentuan Pasal tersebut (Memorie Van Toelichting) melalui penelusuran dokumen dan arsip yang ada di Dewan Perwakilan Rakyat atau di Pemerintah. Dengan demikian Komisi Informasi dapat memahami keinginan dari legislator dan Pemerintah dari dimunculkannya ketentuan ini.

Kedua, penafsiran yang dapat dilakukan oleh Komisi Informasi adalah melalui penafsiran sistematis. Penafsiran sistematis adalah metode penafsiran yang melihat hukum adalah suatu sistem, maka dalam memahami suatu pasal dalam Undang-Undang dibutuhkan untuk memahami pasal pasal lain di dalam Undang-Undang tersebut, dan juga memahami pasal-pasal di Undang-Undang lainnya yang memiliki keterkaitan.

Untuk memberikan penafsiran terhadap Pasal 17 huruf b UU KIP maka dapat merujuk pada norma-norma yang mengatur tentang hal ini di UU lain, yaitu UU Anti Monopoli dan UU Rahasia Dagang. Informasi yang termasuk ke dalam informasi yang dirahasiakan menurut Pasal 23 UU Anti Monopoli adalah informasi kegiatan usaha perusahaan yang dikategorikan sebagai informasi rahasia. Adapun Pasal 2 UU Rahasia Dagang menyatakan bahwa yang disebut informasi yang bersifat rahasia dagang dan wajib mendapatkan perlindungan adalah meliputi: (i) metode produksi, (ii) metode pengolahan, (iii) metode penjualan, atau (iv) informasi lain di bidang teknologi dan/atau bisnis yang memiliki nilai ekonomi dan tidak diketahui oleh masyarakat umum.

Untuk memerinci Pasal 2 UU Rahasia Dagang, Komisi Informasi dapat menggunakan metode penafsiran sosiologis dengan meminta pendapat praktisi dagang, ahli ekonomi, ahli hukum dagang, agar diperoleh pemahaman yang lengkap. Hal ini dimungkinkan agar putusan Komisi Informasi bersesuaian dengan alam pikir dan praktik yang hidup dan tumbuh berkembang di tengah-tengah pasar.

Dengan menggunakan tiga metode penafsiran ini, maka ketentuan yang terdapat di dalam Pasal 17 huruf $\mathrm{b}$ dapat dioperasionalkan dan dapat memberikan kepastian hukum kepada pelaku usaha, pemohon infomasi, Komisi Informasi, dan masyarakat luas.

\section{Perlindungan Hukum Terhadap Informasi Rahasia Pelaku Usaha}

Jangkauan rezim hukum keterbukaan informasi hanya terhadap badan publik yang memenuhi karakteristik Pasal 1 ayat (3) UU KIP. Pelaku usaha yang memenuhi syarat sebagai badan publik memiliki kewajiban untuk menyampaikan informasi secara berkala, mengumumkan informasi secara serta merta, dan menyediakan informasi tersedia setiap saat.

Rezim hukum ini tidak menjangkau pelaku usaha yang bukan badan publik. Lantas, bagaimana bila terdapat informasi rahasia milik pelaku usaha yang dikuasai badan publik, sebagai contoh, Komisi Pengawas Persaingan Usaha menguasai informasi rahasia milik pelaku usaha, dimohonkan oleh pemohon informasi? Mengingat Komisi Pengawas Persaingan Usaha adalah badan publik yang memiliki kewajiban untuk mengumumkan informasi publik dan juga berkewajiban untuk menyediakan informasi setiap saat serta memenuhi permohonan informasi publik.

Untuk menjawab hal ini, sebenarnya telah terjadi harmonisasi antar UU KIP, UU Anti Monopoli, dan UU Rahasia Dagang. Pasal 17 huruf j UU KIP menyatakan bahwa informasi tidak boleh diungkapkan berdasarkan Undang-Undang. Pasal 3 ayat (1) UU Rahasia Dagang 
menyatakan bahwa Rahasia Dagang mendapat perlindungan apabila informasi tersebut bersifat rahasia, mempunyai nilai ekonomi, dan dijaga kerahasiaannya melalui upaya sebagaimana mestinya. Adapun karateristik informasi rahasia dagang diatur dalam Pasal 3 ayat (2) dan (3) adalah sebagai berikut: (i) Informasi dianggap bersifat rahasia apabila informasi tersebut hanya diketahui oleh pihak tertentu atau tidak diketahui secara umum oleh masyarakat, (ii) Informasi dianggap memiliki nilai ekonomi apabila sifat kerahasiaan informasi tersebut dapat digunakan untuk menjalankan kegiatan atau usaha yang bersifat komersial atau dapat meningkatkan keuntungan secara ekonomi.

Berdasarkan harmonisasi tiga Undang-Undang ini, sesungguhnya setiap badan publik yang menguasai informasi rahasia milik pelaku usaha diwajibkan menjaga kerahasiaannya. Pengaturan tentang perlindungan usaha terhadap pelaku usaha sudah sangat jelas. Rezim keterbukaan informasi publik telah dilengkapi oleh UU Anti Monopoli dan UU Rahasia Dagang.

\section{KESIMPULAN}

Selain hakim dan pejabat administrasi negara, terdapat lembaga lain yang berfungsi menerapkan hukum, yaitu lembaga negara bantu, sesuai dengan tugas dan wewenang yang diberikan peraturan perundang-undangan. Komisi Informasi sebagai lembaga negara bantu diberi tugas berdasarkan UU KIP adalah menerima, memeriksa, dan memutus perkara sengketa informasi yang disampaikan pemohon informasi juga menerapkan dan menafsirkan hukum.

Perlindungan usaha di Indonesia telah mendapatkan perlindungan hukum, hal ini diatur di dalam UU KIP, UU Anti Monopoli, dan UU Rahasia Dagang. Pasal 17 huruf j UU KIP menyatakan bahwa informasi tidak boleh diungkapkan berdasarkan Undang-Undang. Pasal 3 ayat (1) UU Rahasia Dagang menyatakan bahwa Rahasia Dagang mendapat perlindungan apabila informasi tersebut bersifat rahasia, mempunyai nilai ekonomi, dan dijaga kerahasiaannya melalui upaya sebagaimana mestinya. Adapun karateristik informasi rahasia dagang diatur dalam Pasal 3 ayat (2) dan (3) adalah sebagai berikut: (i) Informasi dianggap bersifat rahasia apabila informasi tersebut hanya diketahui oleh pihak tertentu atau tidak diketahui secara umum oleh masyarakat, (ii) Informasi dianggap memiliki nilai ekonomi apabila sifat kerahasiaan informasi tersebut dapat digunakan untuk menjalankan kegiatan atau usaha yang bersifat komersial atau dapat meningkatkan keuntungan secara ekonomi.

Rezim hukum keterbukaan informasi publik tidak menjangkau pelaku usaha yang bukan badan publik. Badan publik yang menguasai informasi rahasia pelaku usaha non badan publik diwajibkan menjaga kerahasiaannya. Hal ini berdasarkan Pasal 17 huruf j UU KIP yang menyatakan bahwa informasi tidak boleh diungkapkan berdasarkan Undang-Undang dan Pasal 3 ayat (1) UU Rahasia Dagang menyatakan bahwa Rahasia Dagang mendapat perlindungan apabila informasi tersebut bersifat rahasia, mempunyai nilai ekonomi, dan dijaga kerahasiaannya melalui upaya sebagaimana mestinya. 


\section{DAFTAR PUSTAKA}

Riduan Syahrani, Seluk Beluk Dan Asas-Asas Hukum Perdata, Penerbit Alumni, Bandung, 2004

E. Utrecht/Moh. Saleh Jindang, Pengantar Dalam Hukum Indonesia, Sinar Harapan, 1982

Sudikno Mertokusumo, Penemuan Hukum sebuah pengantar, Penerbit Liberty Yogyakarta, 2009.

E. Utrecht/Moh. Saleh Jindang, Pengantar Hukum Administrasi Indonesia, Sinar Harapan, 1990

Miranda Risang Ayu, "Kedudukan Komisi Independen sebagai State Auxiliary Institutions dan Relevansinya dalam Struktur Ketatanegaraan Indonesia", Jurnal Konstitusi, PSKN-FH Universitas Padjadjaran, Jakarta, 2009

Lembaga Negara dalam masa Transisi Demokrasi, FH. UII Press, Yogyakarta, 2007

Undang-Undang Nomor 5 Tahun 1999 Tentang Larangan Praktik Monopoli Dan Persaingan Usaha Tidak Sehat.

Undang-Undang Nomor 30 Tahun 2000 Tentang Rahasia Dagang

Undang-Undang Nomor 14 Tahun 2008 Tentang Keterbukaan Informasi Publik. 